Hydrol. Earth Syst. Sci. Discuss., doi:10.5194/hess-2016-219, 2016

Manuscript under review for journal Hydrol. Earth Syst. Sci.

Published: 6 June 2016

\title{
Particulate matter characterization of Cauca River water in Colombia
}

\author{
Juan Pablo Gutiérrez ${ }^{1,2}$, Doris van Halem ${ }^{1}$, Luuk Cornelis Rietveld ${ }^{1}$ \\ ${ }^{1}$ Civil Engineering Department, Delft University of Technology, Delft, 2628CN, Netherlands
}

$5{ }^{2}$ Cinara Institute, Faculty of Engineering, Universidad del Valle, Cali, 76001, Colombia

Correspondence to: Juan Pablo Gutiérrez (J.P.GutierrezMarin@tudelft.nl; juan.p.gutierrez@correounivalle.edu.co)

\begin{abstract}
The particulate matter composition in the Upper Cauca River section was studied, considering the importance of this river for the water supply of Cali, Colombia, and the implications that the turbidity of this water source has had for the city's water treatment. Additionally, the upstream Palo River was investigated, as this river is a major contributor to the

10 Cauca River. River water samples were taken in both rivers in the period 2012-2014 during dry and rainy seasons. The origin of the particulate matter was studied through measurements of turbidity, total suspended solids (TSS), volatile suspended solids, particle size distribution, $\mathrm{Fe}^{3+}, \mathrm{PO}_{4}{ }^{3-}, \mathrm{NO}_{3}-\mathrm{N}$, chlorophyll-a, chemical oxygen demand, and true color. Turbidity and TSS values, measured during this survey, were highly variable, ranging from 25 to $465 \mathrm{NTU}$ and 10 to $490 \mathrm{mg} / \mathrm{L}$ in the Cauca River, and from 30 to 840 NTU and 15 to $710 \mathrm{mg} / \mathrm{L}$ in the Palo River, respectively. High scattering was obtained in

15 TSS and turbidity relationships in both rivers, potentially due to the different sources contributing to both parameters. It was concluded that the concentration of particulate matter depended merely on precipitation events in the Cauca and Palo River basins, leading to soil erosion due to extensive and intensive agricultural practices. In addition, the South Canal was identified as one of the main contributors to organic particulate matter.
\end{abstract}

\section{Introduction}

20 In rural and urban areas of Colombia safe drinking water supply is one of the most serious concerns for public health. Health risks in drinking water supply are predominantly associated with water quality problems in surface water, because approximately $80 \%$ of the water supply in Colombia depends on surface water (Ministerio de Desarrollo de Colombia, 1998). In the past decades, forests have been replaced by bared surfaces due to urbanization, which has increased the concentration of particulate matter in streams and rivers (EPA, 1999; Mulliss et al., 1996). Particulate matter creates turbidity and imparts color to the water. The more sediments enter the water, the higher the turbidity, and the lower the transparency. Turbidity may be caused by silt, clay, organic, inorganic, soluble colored organic compounds, plankton, and microscopic organisms (ASTM, 2003).

Erosion is considered to be one of the main contributors to turbidity, which also occurs naturally due to the action of wind, rain and the river flow. The effect of river flows on particulate matter concentration mainly depends on the slopes, the presence of rocks and rocky fragments (e.g. mountain rivers), promoting riverbed deepening by scouring, destabilizing the 
Hydrol. Earth Syst. Sci. Discuss., doi:10.5194/hess-2016-219, 2016

Manuscript under review for journal Hydrol. Earth Syst. Sci.

Published: 6 June 2016

(c) Author(s) 2016. CC-BY 3.0 License.

riverbank. Flowing water has a tremendous capacity to carry material, often for a long distance (Toy et al., 2002). Although erosion of soil is considered to be a major contributor to the particulate matter in water, other natural and anthropogenic factors can increase the organic-based particulate matter and the inorganic-based particulate matter such as clay, silt and fine sand, and stimulate growth of algae and zooplankton, due to industrial, urban or agricultural activities (EPA, 1999; Kerr, 5 1995).

Particulate matter can be responsible for interference with drinking water treatment processes, such as filtration and disinfection, and can even be a source of disease-causing organisms (EPA, 2013). Hence, the consequences for drinking water treatment depend on the specific compounds of particulate matter in a water source. The objective of this study is to characterize the particulate matter of the highly turbid water of the Cauca River in Colombia, which passes through the city

10 of Cali. The particulate matter concentration of this water source has become a great constraint for the city's water treatment (Pérez-Vidal et al., 2012). Additionally, the upstream Palo River was investigated, as this river is a major tributary to the Cauca River in terms of water discharge (mean annual flow of $35.9 \mathrm{~m}^{3} / \mathrm{s}$ ) and suspended sediments (mean annual sediment load of $0.645 \times 10^{6}$ ton) according to CVC and Universidad del Valle $(2004,2000)$.

\section{Materials and methods}

\section{$15 \quad 2.1$ Study area}

Cali is the capital of the Valle del Cauca Department, located in the southwest part of Colombia between the Central Mountain Range and the Pacific Ocean (Figure 1). It is the third largest city of the country, with $560 \mathrm{~km}^{2}$ of municipal area. $77 \%$ of the drinking water demand in the city is covered by Cauca River water through the water treatment plants (WTPs) Puerto Mallarino and Río Cauca (PDA, 2008).

20 The Cauca River is the second most important surface water source in Colombia and is the main tributary of the Magdalena river basin, with a length of $1,350 \mathrm{~km}$ and an area of approximately $63,300 \mathrm{~km}^{2}$. The Cauca River runs through the western region of the country, which has geological characteristics related to oceanic crust with volcanic rocks (IDEAM, 2004). The Cauca river basin is divided and classified into three sections: the Upper Cauca, the Middle Cauca and the Lower Cauca. The Upper Cauca area, where Cali is located, has the highest population density, with its extensive demand for domestic,

25 agricultural and industrial water supply (CVC and Universidad del Valle, 2004).

The study was executed at two points in the Cauca River basin: the Cauca River at WTP Puerto Mallarino water intake

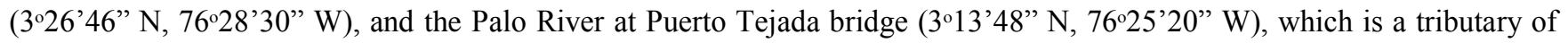
the Cauca River upstream Puerto Mallarino (Figure 1). 
Hydrol. Earth Syst. Sci. Discuss., doi:10.5194/hess-2016-219, 2016

Manuscript under review for journal Hydrol. Earth Syst. Sci.

Published: 6 June 2016

\subsection{Approach}

The approach of the study was to first identify the possible sources of particulate matter in the Cauca and Palo rivers, by studying literature and reports. Afterwards, water samples from both rivers were extracted and water quality analyses were conducted in order to confirm the origin of the particulate matter in relation to potential natural and anthropogenic sources.

\section{$5 \quad 2.3$ Sampling protocol}

River water samples were taken in both rivers in the period 2012-2014 during dry and rainy seasons. In the Upper Cauca a bimodal temporal distribution of precipitations exist (dry period from January to March and from July to September; rainy periods from April to June and from October to December). During this survey, because reduced rainy periods occurred, the rainy season samples correspond to the first showers of the season. The parameters used to characterize particulate matter in

10 the rivers were: turbidity, total suspended solids (TSS), particle size distribution, non-soluble iron ( $\mathrm{Fe}^{3+}$ ), and chlorophyll-a (Chl-a). Phosphate $\left(\mathrm{PO}_{4}{ }^{3-}\right)$ and nitrate $\left(\mathrm{NO}_{3}-\mathrm{N}\right)$ were also measured to evaluate the potential for biological activity. In addition, chemical oxygen demand (COD), true color and volatile suspended solids (VSS) were measured in the Cauca River to obtain an indication of the organic fraction of the particulate matter.

Since the Palo River has a depth smaller than one meter, the sampling was done at half the depth of the water course. For the

15 Cauca River two samples were extracted, one at $20 \%$ of the depth and one at $80 \%$ of the depth of the water course, considering that the depth of the water course is greater than one meter (Curtis et al., 1979; Nordin Jr. and Dempster Jr., 1963) (Figure 2). To extract the water samples a cylindrical stainless steel column was used (40 cm long and $10 \mathrm{~cm}$ ID), designed to sample vertically from the top of the column once the column reached the selected depth.

\subsection{Sample analysis}

20 The determination of the parameters was done according to the Standard Methods (Rice et al., 2012). Turbidity was determined by the Nephelometric Method 2130 B; TSS by 2540 D Total Suspended Solids Method (dried at 103-105 ${ }^{\circ}$ C); VSS by 2540 E Fixed and Volatile Solids (ignited at $550^{\circ} \mathrm{C}$ ); particle size determination in water samples by using a wet sample dispersion unit (Model Hydro 2000SM, Malvern). $\mathrm{Fe}^{3+}$ was determined by measuring total iron minus $\mathrm{Fe}^{2+}$, where total iron was determined through the 3500-Fe B Phenanthroline Method and $\mathrm{Fe}^{2+}$ by using the same method but filtering the samples in situ with $0.45 \mu \mathrm{m}$ Whatman Protran Nitrocellulose Membrane Filters. ESS Method 150.1 Spectrophotometric was used to determine Chl-a; 5220 D Closed Reflux Colorimetric Method for COD; 4500-P D Stannous Chloride Method for $\mathrm{PO}_{4}{ }^{3-} ; 4500-\mathrm{NO}_{3}{ }^{-}$D Nitrate Electrode Method for $\mathrm{NO}_{3}-\mathrm{N}$. TOC values correspond to field measurements done in Cauca River through an electrical probe (Hach UVAS plus sc UV Absorbance / \% Transmittance Sensor). True color was determined by spectrophotometric method $2120 \mathrm{C}$. 
Hydrol. Earth Syst. Sci. Discuss., doi:10.5194/hess-2016-219, 2016

Manuscript under review for journal Hydrol. Earth Syst. Sci.

\section{Results}

\subsection{Identification of potential sources of particulate matter}

The Cauca River basin in the Cauca department, where the river springs, has an area of 7,394.8 $\mathrm{km}^{2}$. The largest part of the Cauca department is used for commercial farming of pine, coffee, plantain, flowers, cassava, and beans. There are also small

5 scale fishing activities, cattle breeding and agriculture exploitation by indigenous groups and the paper and sugar industry plays an important role in the land use. In addition, gold, bauxite and coal mining are relevant activities (UPME, 2005; Zibechi, 2014), which have affected soil and water resources (Conpes, 2009; EMCALI and Universidad del Valle, 2006). The part of the Cauca River basin situated in the Valle del Cauca department is mainly used for extensive livestock farming in natural pastures, followed by sugar cane and perennial crops. Only a small portion of the basin is occupied by forest

10 (Ekstrand et al., 2009). Therefore, around 54\% of the total area has some degree of erosion, of which $31 \%$ is severely eroded (Ekstrand et al., 2009).

The basin of the Palo River has also been suffering from continuous soil deterioration (Cifuentes, 2014; CRC and CIAT, 2007). Moreover, large sugar mills are located in the lower Palo River basin, in addition to food and beverage processing industries, paper-manufacturing factories and other factories (Cifuentes, 2014). In this area, there are also semi-permanent

15 agricultural activities such as the cultivation of sugar cane, corn, soybeans and sorghum. The middle and upper basins of the Palo River are characterized as agricultural areas with traditional cultural farming practices. In the middle and lower basin, the surface water is affected by progressive industrial and domestic discharges, the slums situated around the river, extensive and intensive agricultural activities and cattle breeding activities along its entire basin (Cifuentes, 2014).

In Table 1 a systematic overview of the potential sources of particulate matter in the Upper Cauca River and the Palo River 20 is presented, with its characteristics.

\subsection{Seasonal fluctuation of turbidity and TSS}

Both the dry and rainy seasons were characterised by lower than average precipitation (Cenicaña, 2014). The sampling points in the Cauca River (at 20\% depth (P1) and at 80\% depth from surface (P2)) showed a substantial strength of agreement (McBride, 2005), where with a sample size of 13, the concordance correlation coefficient was 0.98 and 0.99 for turbidity and TSS, respectively. This indicates a well-mixed water mass at the measuring point at WTP Puerto Mallarino, and therefore the samples at different depths were further considered as duplicates.

There was a considerable difference in the turbidity and TSS values between the dry and rainy seasons for both rivers as demonstrated by the higher turbidity and TSS values during the rainy season than during the dry season (Figure 3). During the dry season the turbidity ranged between 24 and 107 NTU in the Cauca River, and between 28 and 131 NTU in the Palo

30 River. During the rainy season the turbidity ranged from 32 to 465 NTU in the Cauca River and from 70 to 840 NTU in the Palo River. The turbidity and TSS peaks were higher in the Palo River than in the Cauca River. 
Hydrol. Earth Syst. Sci. Discuss., doi:10.5194/hess-2016-219, 2016

Manuscript under review for journal Hydrol. Earth Syst. Sci.

River discharges were monitored, obtaining relatively constant values during the monitoring campaign for both rivers (116 to $255 \mathrm{~m}^{3} / \mathrm{s}$, with a mean of $150 \mathrm{~m}^{3} / \mathrm{s}$ for the Cauca River; 33 to $73 \mathrm{~m}^{3} / \mathrm{s}$, with a mean of $43 \mathrm{~m}^{3} / \mathrm{s}$ for the Palo River). Pearson correlation coefficient, $r$, was determined between river discharges and turbidity and TSS, finding a weak relationship for both rivers ( 0.53 for turbidity and 0.59 for TSS in the Cauca River; 0.31 for turbidity and 0.27 for TSS in the Palo River).

\section{$5 \quad 3.3$ Turbidity and TSS relation}

Turbidity was plotted against TSS data (Figure 4), showing a similar trend for both rivers, although scattering was observed in both rivers. This scattering was more obvious for TSS values below $100 \mathrm{mg} / \mathrm{L}$ in both rivers during the dry season (see the weak $r$ coefficient in Figure 4a). In the Palo River only four data points above the $100 \mathrm{mg} / \mathrm{L}$ were obtained during the monitoring campaign ${ }^{1}$.

\section{3.4 Particle size distribution}

The relationships between TSS and particle size distribution are illustrated in Figure 5; only minor differences were observed between the dry and rainy season for both rivers. TSS comprised of 5\% particles smaller than $2 \mu \mathrm{m}, 80 \%$ particles between 2 and $50 \mu \mathrm{m}$ and $15 \%$ of particles between 50 and $250 \mu \mathrm{m}$, during both seasons.

For both rivers a slightly higher content of fine particles $(<2.0 \mu \mathrm{m})$ was observed during the rainy season than during the dry

15 season. Figure 5 shows a wider right tail in the Palo River (b) than in the Cauca River (a), indicating that TSS in the Palo River also contained particles with a larger size than the ones found in the Cauca River.

\subsection{Volatile suspended solids}

Figure 6 presents the VSS fractions found in the Cauca River in 70 samples, classified in relation to TSS ranks. For all TSS ranks the volatile fraction is lower than the fixed fraction; however, differences in fractions among ranks can be observed.

20 For TSS $>100 \mathrm{mg} / \mathrm{L}$ (i.e. rainy events), the volatile fraction represented about $28 \%$ of the TSS, while for lower TSS values (i.e. dry events), the volatile fraction was around $40 \%$ of the TSS. A considerable scattering was observed for all the TSS ranks (STD close to $0.11,0.12$ and 0.20 for TSS $<50 \mathrm{mg} / \mathrm{L}, 50 \mathrm{mg} / \mathrm{L}<\mathrm{TSS}<100 \mathrm{mg} / \mathrm{L}$ and TSS $>100 \mathrm{mg} / \mathrm{L}$, respectively).

\subsection{Iron and phosphate}

$\mathrm{Fe}^{3+}$ concentrations were constant during the dry period until an intense rain event altered the iron concentration in both the

25 Palo River and the Cauca River. The $\mathrm{Fe}^{3+}$ concentrations were 1.97 to $8.85 \mathrm{mg} / \mathrm{L}$ for the Cauca River, and 2.38 to $6.10 \mathrm{mg} / \mathrm{L}$ for the Palo River, respectively, and consistent during the study.

\footnotetext{
${ }^{1}$ No more data could be obtained due to safety issues at the sampling site; therefore, for Palo River, it was not possible to establish an accurate relationship of turbidity and TSS at high turbidity events.
} 
Hydrol. Earth Syst. Sci. Discuss., doi:10.5194/hess-2016-219, 2016

Manuscript under review for journal Hydrol. Earth Syst. Sci.

Published: 6 June 2016

Figure 7 shows that at higher TSS concentrations, also higher $\mathrm{Fe}^{3+}$ concentrations were measured in both rivers and for high TSS values (> $100 \mathrm{mg} / \mathrm{L}$ ) a broader range of $\mathrm{Fe}^{3+}$ concentrations was measured.

Phosphate concentrations also increased with increasing TSS (Figure 8). During both the dry and rainy seasons for both rivers, phosphate concentrations exceeded the usual values in surface waters under natural conditions $(0.005-0.02 \mathrm{mg} / \mathrm{L}$;

5 UNESCO, 1996). For the Cauca River, phosphate concentrations ranged between 0.05 to $1.21 \mathrm{mg} / \mathrm{L}$, exceeding the values reported in a previous study $(0.04-0.08 \mathrm{mg} / \mathrm{L} ; \mathrm{CVC}$ and Universidad del Valle, 2004). For the Palo River, it ranged from 0.22 to $3.90 \mathrm{mg} / \mathrm{L}$. At TSS > $100 \mathrm{mg} / \mathrm{L}$, thus much higher concentrations were found in the Palo River than in Cauca River.

\subsection{Other water quality parameters}

COD values found in this study were 103 to $160 \mathrm{mg} / \mathrm{L}$ for Cauca River and 124 to $179 \mathrm{mg} / \mathrm{L}$ for Palo River, respectively.

10 The values were much higher than the typical values reported earlier (CVC and Universidad del Valle, 2004; Reyes, 2009). As pointed out by CVC and Universidad del Valle (2004), COD concentrations in the Cauca River usually range between 10 and $30 \mathrm{mg} / \mathrm{L}$. According to the report by Reyes (2009), COD values in the Palo River range between 4.7 and $33 \mathrm{mg} / \mathrm{L}$.

$\mathrm{N}-\mathrm{NO}_{3}$ concentration values $\left(2.5\right.$ to $\left.11.0 \mathrm{mg} \mathrm{N}-\mathrm{NO}_{3} / \mathrm{L}\right)$ measured in the Cauca River were also above the values reported by CVC and Universidad del Valle (2004) during a ten-year measuring period (1993 to 2003). In that period $\mathrm{N}-\mathrm{NO}_{3}$

15 concentrations ranging from 0.1 to $0.4 \mathrm{mg} \mathrm{N}-\mathrm{NO}_{3} / \mathrm{L}$ were observed near WTP Puerto Mallarino. In the Palo River $\mathrm{N}_{-} \mathrm{NO}_{3}$ concentrations were measured ranging from 1.3 to $10.0 \mathrm{mg} \mathrm{N}-\mathrm{NO}_{3} / \mathrm{L}$. In the Cauca River concentrations were found between 2.5 and $11.0 \mathrm{mg} / \mathrm{L}$ for dry conditions, and 4.5 and $11.0 \mathrm{mg} / \mathrm{L}$ during the rainy season. While, in Palo River values were measured between 1.3 and $10.0 \mathrm{mg} / \mathrm{L}$ for dry conditions, and ranging from 6.1 to $9.7 \mathrm{mg} / \mathrm{L}$ during the rainy season. Thus, no considerable differences in $\mathrm{N}-\mathrm{NO}_{3}$ concentrations between both rivers were observed. Only some differences between both

20 seasons in Palo River were observed.

Chl-a data were quite irregular without showing a clear trend $\left(1550\right.$ to $8100 \mu \mathrm{g} / \mathrm{m}^{2}$ in the Cauca River; 920 to $5960 \mu \mathrm{g} / \mathrm{m}^{2}$ in the Palo River). True color measurements ranged from 29 to 155 TCU and 17 to 191 TCU in Cauca River and Palo River, respectively. These values also correspond to the ranges found during the dry season (29 to 155 TCU for Cauca River and 17 to 191 TCU for Palo River). During the rainy season, values varied from 57 to 124 TCU in the Cauca River and from 33 to

$25121 \mathrm{TCU}$ in the Palo River.

\section{Discussion}

\subsection{River discharges and/or precipitation events as particulate matter precursors}

Previous studies have reported that TSS depends on changes in river discharge (Meybeck et al., 2003; Susfalk et al., 2008; Ziegler et al., 2011). However, an upstream reservoir (Salvajina dam) controls the water discharge in the Cauca River;

30 therefore, discharge does not depend on precipitation events only, but mainly on the operation of the dam gates (Ramírez et al., 2010). Thus, in the Cauca River considerable changes in water discharges were not observed during the monitoring 
Hydrol. Earth Syst. Sci. Discuss., doi:10.5194/hess-2016-219, 2016

Manuscript under review for journal Hydrol. Earth Syst. Sci.

Published: 6 June 2016

(c) Author(s) 2016. CC-BY 3.0 License.

campaign, despite the variations in turbidity and TSS values. Göransson et al. (2013) also reported the lack of relationship between discharge and TSS and turbidity in a regulated river system.

A comparison with other tropical lowland rivers shows that the Cauca River exhibited some unusual features in its temporal patterns of turbidity and TSS values (Jansson, 1992; Wu et al., 2014). Turbidity and TSS values in the Cauca River were higher than expected for tropical lowland rivers, while seasonal changes in flow were not evident. After the construction of the Salvajina's dam, lower discharges were observed in the Cauca River, but the sediment loads have been increasing over the years, leading to the occurrence of earlier and longer turbidity peaks (EMCALI, 1987).

\subsection{Particulate matter source}

In Table 2 the expected origins of the different measured parameters are described, also in relation to literature, while different scenarios of water discharge (high or low) were considered.

\subsubsection{Natural erosion}

As pointed out by different authors, the relationship between turbidity and TSS is watershed specific, but is generally strong (Gippel, 1995; Lewis et al., 2002; Packman et al., 1999; Susfalk et al., 2008; Wu et al., 2014). The weak relationship between turbidity and TSS suggests the presence of suspended colored organic compounds interfering with turbidity

15 measurements, which is supported by the high true color values found in both rivers and the relatively high VSS percentages (Gippel, 1995; Packman et al., 1999). This is generally found in lentic water bodies like bogs, wetlands, and lakes with high concentrations of decaying vegetation in the water (Furukawa et al., 2014; Mitchell and Prepas, 1990; Volk et al., 2002). The presence of colored organic compounds may be associated with the effect of the Salvajina's dam, leading to the accumulation of organic matter because of the stagnant phase in the dam (Nadon et al., 2015). These particles remain in

20 suspension as wash load once the stored water is delivered to the river. The larger particle sizes found in Palo River may be a consequence of the higher velocities leading to higher shear stress forces in the Palo River able to re-suspend larger particles from the river bottom.

\subsubsection{Human-induced particulate matter}

Phosphate, nitrate and COD results in this study fall within the classification of contaminated surface waters (UNESCO,

25 1996), indicating agricultural activities around the Cauca and Palo rivers, involving the use of fertilizers. In addition, industrial, domestic and mining activities could contribute to the high concentrations of these compounds.

\section{- Human-induced erosion}

In the Cauca River basin, the main anthropogenic sources of sediments to waterways are likely to be land clearing and 30 degradation from over grazing and a loss of soil cover associated with extensive scale cropping. Also, people migrating to forest frontiers due to forced displacement (slums), has conveyed into deforestation because of forest burning and clearing 
Hydrol. Earth Syst. Sci. Discuss., doi:10.5194/hess-2016-219, 2016

Manuscript under review for journal Hydrol. Earth Syst. Sci.

Published: 6 June 2016

(c) Author(s) 2016. CC-BY 3.0 License.

for subsistence (Conpes, 2009). Since the dam diminishes variations in the sediment transport capacity of the Cauca River caused by shear stress forces in the river itself, the suspended sediment variations are probably due to eroded soils caused by precipitation events. As water discharges were also rather constant in the Palo River (due to the low precipitation intensities presented in the Palo River basin during this monitoring campaign), but variations in turbidity and TSS occurred, detachment

5 of particulate material when soils are dragged during the first rain events may also be assumed to be an important phenomenon contributing to the found values in the Palo River.

The contribution of agricultural practices is supported by the link between phosphates and TSS (Figure 8). The higher phosphate concentrations found in the Palo River at higher TSS values (TSS > $100 \mathrm{mg} / \mathrm{L}$ ) may be due to both the extensive and intensive agricultural practices in the Palo River basin, having as a result that large areas of bared soils, containing

10 phosphates from fertilizers, are washed out during the first rainfall events. In the Cauca River lower phosphate concentrations were observed at TSS $>100 \mathrm{mg} / \mathrm{L}$ than in the Palo River, due to the lower degree of agricultural activities per land surface.

Nitrate concentrations were much higher than the reported until 2003 by CVC and Universidad del Valle (2004), indicating a considerable deterioration of the Cauca River basin. The measured values are common in contaminated rivers and river 15 catchments affected by agricultural activities (Meybeck, 1982; Mitchell et al., 2009). As observed in Table 2, the nitrate concentration is expected to decrease as water discharge increases due to dilution. However, during this survey a similarity was observed in values obtained in Cauca River for both seasons, suggesting an increase in nitrate discharges entering into the Cauca River as the river discharge increases, mainly associated to runoff containing soil-bound nitrate.

In the Palo River, the differences between seasons in nitrogen to phosphorus (N:P) ratio indicates that during shower events

20 the phosphorus concentration migrating from the catchment to the river increased considerably, decreasing the molar N:P ratio (24:1 for dry conditions and 18:1 for rainy conditions respectively in the Palo River). The variation between seasons in the Palo River may be attributed to the infrequent rain events leading to the soil loss from the catchment having a higher phosphorus than nitrate content (Figure 8). The Chl-a results indicate, according to Mitchell and Prepas (1990), a low presence of phytoplankton and/or algae in both surface waters. The development of phytoplankton and/or algae may be

25 limited by the turbidity (Correll, 1999; Hecky and Kilham, 1988; Skidmore et al., 1998) affecting the light intensity and/or light quality, and by the effect of turbulent mixing of the rivers inhibiting its growth (Hondzo and Lyn, 1999; Smayda, 2002), supported by the similar turbidity and TSS values at different depths in the Cauca River. Although the N:P in both seasons exceeds the Redfield ratio (16:1) (Hecky and Kilham, 1988), the high phosphorus and nitrate concentrations found in both rivers during both seasons indicate that both parameters cannot be pointed out as a limiting nutrient for algal growth

30 (Correll, 1999).

Although a weak relationship between TSS and turbidity was obtained, a similarity in slopes between both rivers was found. This indicates that the sources of suspended solids of the Cauca River and the Palo River were related in both rivers (Lewis et al., 2002), where smaller particles $(<2.0 \mu \mathrm{m})$ were found during rainy season (see Figure 5). The slightly higher content of colloidal particles during the rainy season (Figure 5) may be due to changes in vegetation coverage and decomposed 
Hydrol. Earth Syst. Sci. Discuss., doi:10.5194/hess-2016-219, 2016

Manuscript under review for journal Hydrol. Earth Syst. Sci.

Published: 6 June 2016

organic matter in the runoff. Higher true color values were observed in the Palo River, associated to the higher colloidal particles found in the Palo River. This may be explained by the land use in the river basin, because $68 \%$ of the area of the Palo River basin is covered by crops and pastures with agricultural uses and livestock (Cifuentes, 2014).

The higher non-soluble iron concentrations found at high TSS values, where higher water discharges occurred, also suggests

5 a contribution of deforestation and agriculture activities to suspended particulate matter in the river. In the Cauca and Palo rivers, a relation between iron concentrations and TSS was found during both seasons (Figure 7), which is supported by the brownish-reddish coloration of the river waters. The presence of iron in both rivers can be explained by the characteristics of the soils in the Upper Cauca River and the Palo River basins (FUDESO, n.d.). The brownish-reddish coloration of the soils indicates the existence of iron oxide minerals (Bastidas-Obando and Carbonell, 2010; Kritzberg and Ekström, 2012).

10 Although literature has, to the authors' knowledge, not reported relationships between turbidity and non-soluble iron in rivers, Riera and Armengol (1995) stated a strong relationship between both parameters in reservoirs associated with mineral particles, suspended sediments and detrital organic matter due to inputs from the watershed.

\section{- $\quad$ Mining}

15 Although other metal concentrations were not measured during this survey, the increase of TSS-turbidity during shower events may also be related to legal and illegal mining activities and the removal of dragging materials (Ekstrand et al., 2009; Universidad del Valle and UNESCO-IHE, 2008). Open-pit and underground mining activities in the Palo River basin, and other sub basins draining to the Cauca River, has been identified to be developed, leading to soil degradation and an augmentation in the turbidity levels in some of the tributary rivers (Conpes, 2009). However, it is expected that the

20 contribution of mining to particulate matter found in the Cauca River is negligible based on the scale of mining activities compared to the agricultural practices. This is also supported by the weak influence of river discharge, on e.g. non-soluble iron concentrations, expecting lower concentrations at higher river discharges in case of excessive mining activities (see Table 2).

In the Cauca River higher COD values were found during the rainy season than during dry season, due to the effect of the socalled South Canal on the Cauca River. Storm water, transported by the South Canal, carries domestic and industrial wastewater discharges, and leachates from the already closed landfill of the city of Cali. In addition, large amounts of 30 sediments are deposited on the canal bottom. During rainy events, resuspension of the deposited sediments containing contaminants occur (first flush effect), showing important modifications in water quality at the Cauca River once shower events occur (Galvis et al., 2014). The first flush effect has been recognized as an important contributor to sediment peaks during strong rainy events (Hurtado, 2014; Universidad del Valle and UNESCO-IHE, 2008; Vélez et al., 2006). During the 
Hydrol. Earth Syst. Sci. Discuss., doi:10.5194/hess-2016-219, 2016

Manuscript under review for journal Hydrol. Earth Syst. Sci.

Published: 6 June 2016

(c) Author(s) 2016. CC-BY 3.0 License.

rainy season low river discharges existed because of the operation of the Salvajina's dam diminishing the dilution capacity of the sediments-contaminants washed out from the South Canal to the Cauca River.

\section{Conclusions}

The particulate matter concentration has been considered as a key parameter for drinking water treatment. Considering the

5 importance of the Cauca River for the water supply of Cali, Colombia, the composition of the particulate matter in this river was studied. Characterization of the particulate matter in the Cauca River has shown that the TSS did not depend on river flows, but merely on precipitation events in the Cauca and Palo river basins due to the erosion of soils. Nevertheless, a high scattering was obtained between TSS and turbidity values in both rivers, potentially due to the different sources contributing to both parameters, such as color and particle size. A similar particle size distribution was found during the dry and rainy

10 season for both rivers, having a slightly higher content of particles smaller than $2 \mu \mathrm{m}$ during rainy conditions due to changes in vegetation coverage and decomposed organic matter in the runoff. In the Palo River larger particle sizes were found than in the Cauca River due to the higher velocities registered in Palo River, which has a consequence for the shear stress forces able to re-suspend larger particles. Non-soluble iron was found to correlate well with the TSS load in the Cauca River, also pointing out the importance of erosion of soils during shower events. At high TSS values also higher concentrations of

15 phosphate were found in the Palo River, where extensive and intensive agricultural practices exist. In Cauca River, lower phosphate concentrations were observed, potentially due to the extensive and intensive agricultural practices in the Palo River basin, leading to large areas of bared soils containing phosphates from fertilizers. Based on the results obtained during this survey, extensive and intensive agricultural practices in conjunction with erosive processes, were identified as the main contributors to particulate matter. In addition, the South Canal was considered to have an important effect on the organic

20 particulate matter content in Cauca River during rainy precipitation events. Mining activities were found to have a minor contribution to particulate matter in the rivers, also based on the scale of mining activities compared to the agricultural practices.

Author contributions. All authors jointly designed the sampling protocol. JPG collected and analysed the samples, processed

25 the data and wrote the article, that all authors contributed substantially to revisions.

Acknowledgements. The authors would like to acknowledge the support of Colciencias for the scholarship of Juan Pablo Gutiérrez Marín. Special thanks to Cinara Institute for its support during the data collection and analysis..

\section{References}

30 ASTM: Standard Test Method for Turbidity of Water, D1889-00, ASTM International, Annual Book of ASTM Standards, Water and Environmental Technology, 2003, v. 11.01, West Conshohocken, Pennsylvania, USA., 2003. 
Hydrol. Earth Syst. Sci. Discuss., doi:10.5194/hess-2016-219, 2016

Manuscript under review for journal Hydrol. Earth Syst. Sci.

Published: 6 June 2016

(c) Author(s) 2016. CC-BY 3.0 License.

Bastidas-Obando, E. and Carbonell, J. A.: Caracterización espectral y mineralógica de los suelos del valle del río Cauca por espectroscopía visible e infrarroja (400 - 2,500 nm), Agron. Colomb., 28(2), 291-301, 2010.

Cenicaña: Daily precipitation report 2007-2014 from Cauca River at Cenicaña monitoring station, [online] Available from: http://www.cenicana.org/clima_/index.php\# (Accessed 12 January 2015), 2014.

5 Cifuentes, E.: Análisis de la incidencia de las fuentes de contaminación difusa relacionadas con el uso y las prácticas de manejo del suelo en la producción de sedimentos en la cuenca del río Palo, MSc. Thesis, Universidad del Valle, Cali, Colombia., 2014.

Conpes: Programa para el saneamiento, manejo y recuperación ambiental de la cuenca alta del río Cauca, Ministerio de Ambiente, Vivienda y Desarrollo Territorial, Conpes 3624, Bogotá D.C., Colombia., 2009.

10 Correll, D. L.: Phosphorus: a rate limiting nutrient in surface waters, Poult. Sci., 78(5), 674-682, 1999.

CRC and CIAT: Ubicación y medidas de control de procesos erosivos de la cuenca del río Cauca, Departamento del Cauca, Convenio CRC-CIAT No. 1009-211204., 2007.

Curtis, W. F., Meade, R. H., Nordin, C. F., Price, N. B. and Sholkovitz, E. R.: Non-uniform vertical distribution of fine sediment in the Amazon River, Nature, 280(5721), 381-383, 1979.

15 CVC and Universidad del Valle: Caracterización de ríos tributarios del río Cauca, tramo Salvajina - La Virginia, Corporación Autónoma Regional del Valle del Cauca, CVC. Proyecto de Modelación del Río Cauca - PMC, Fase I. Volumen IV, Cali, Colombia., 2000.

CVC and Universidad del Valle: Caracterización río Cauca. Identificación de parámetros críticos en el río Cauca y sus principales ríos tributarios, tramo Salvajina - La Virginia, Corporación Autónoma Regional del Valle del Cauca, CVC.

20 Proyecto de Modelación del Río Cauca - PMC, Fase II. Volumen IX, Cali, Colombia., 2004.

Ekstrand, S., Mancinelli, C., Houghton-Carr, H., Govers, G., Debels, P., Camaño, B., Alcoz, S., Filiberto, I., Gámez, S. and

Duque, A.: Twinning European and Latin-American river basins for research enabling sustainable water resources management, Project 018436, TWINLATIN., 2009.

EMCALI: Salvajina y comportamiento de la calidad del agua del río Cauca, Correspondencia Interna Sección Operativa

25 PTAP Puerto Mallarino - Departamento de Producción de Agua Potable., 1987.

EMCALI and Universidad del Valle: Informe de campaña de monitoreo y caracterización de los vertimientos de la ciudad de Cali y de la calidad del agua del río Cauca en el tramo Hormiguero-Mediacanoa, Contrato Inter-Administrativo No. 300GAA-CC-491-2005 Project "Evaluation of strategies for managing wastewater from the city of Cali.", 2006.

EPA: Guidance manual for compliance with the interim enhanced surface water treatment rule: turbidity provisions, EPA 30 815-R-99-010, Office of Water., 1999.

EPA: Basic information about pathogens and indicators in drinking water, Water Basic Inf. about Regul. Drink. Water Contam. [online] Available from: http://water.epa.gov/drink/contaminants/basicinformation/pathogens.cfm (Accessed 1 July 2014), 2013.

FUDESO: Plan de Ordenación y manejo de la cuenca hidrográfica del río Cajibío - Urbio y Puente Alto, Fundación para el 
Hydrol. Earth Syst. Sci. Discuss., doi:10.5194/hess-2016-219, 2016

Manuscript under review for journal Hydrol. Earth Syst. Sci.

Desarrollo Ambiental Sostenible - FUDESO., n.d.

Furukawa, Y., Reed, A. H. and Zhang, G.: Effect of organic matter on estuarine flocculation: a laboratory study using montmorillonite, humic acid, xanthan gum, guar gum and natural estuarine flocs., Geochem. Trans., 15(1), 1, 2014.

Galvis, A., Hurtado, I., Martínez-Cano, C. and Urrego, J.: Dynamic condition approach to study the self-purification capacity

5 of Colombian water bodies case: Cauca River and Salvajina Dam, in 11th International Conference on Hydroinformatics, New York, USA., 2014.

Gippel, C. J.: Potential of turbidity monitoring for measuring the transport of suspended solids in streams, Hydrol. Process., 9(1), 83-97, 1995.

Göransson, G., Larson, M. and Bendz, D.: Variation in turbidity with precipitation and flow in a regulated river system-river

10 Göta Älv, SW Sweden, Hydrol. Earth Syst. Sci., 17(7), 2529-2542, 2013.

Hecky, R. E. and Kilham, P.: Nutrient limitation of phytoplankton in freshwater and marine environments: a review of recent evidence on the effects of enrichment, Limnol. Oceanogr., 33(4-2), 796-822, 1988.

Hondzo, M. and Lyn, D.: Quantified small-scale turbulence inhibits the growth of a green alga, Freshw. Biol., 41, 51-61, 1999.

15 Hurtado, C. D.: Análisis de alternativas de solución al problema de discontinuidad en el servicio de agua potable en Cali estudio de prefactibilidad de la planta regional de biorremediación de aguas residuales, Undergraduate Thesis, Universidad del Valle., 2014.

IDEAM: Informe anual sobre el estado del medio ambiente y los recursos naturales renovables en Colombia, Instituto de Hidrología, Meteorología y Estudios Ambientales de Colombia - IDEAM, Bogotá D.C., Colombia., 2004.

20 Jansson, M. B.: Turbidimeter measurements in a tropical river, Costa Rica, in Erosion and Sediment Transport Measurement in Rivers: Technological and Methodological Advances, Workshop, vol. 210, pp. 71-78, Oslo, Norway., 1992.

Kerr, S. J.: Silt, turbidity and suspended sediments in the aquatic environment: an annotated bibliography and literature review, Ontario, Canada., 1995.

Kritzberg, E. S. and Ekström, S. M.: Increasing iron concentrations in surface waters - a factor behind brownification?, 25 Biogeosciences, 9(4), 1465-1478, 2012.

Kryt, J.: Battle in the clouds: in the Colombian Andes, ecosystems are disappearing faster than scientists can study them, Earth Isl. J. 28(2) [online] Available from: http://www.earthisland.org/journal/index.php/eij/article/battle_in_the_clouds/ (Accessed 15 October 2014), 2013.

Lewis, D. J., Tate, K. W., Dahlgren, R. A. and Newell, J.: Turbidity and total suspended solid concentration dynamics in 30 streamflow from California oak woodland watersheds, in Proceedings of the 5th Symposium on Oak Woodlands: Oaks in California's Challenging Landscape, edited by R. B. Standiford, D. McCreary, and K. L. Purcell, pp. 107-118, Gen. Tech. Rep. PSW-GTR-184, Albany, CA: Pacific Southwest Research Station, Forest Service, U.S. Department of Agriculture, Albany, CA, USA., 2002.

López, A.: The Cauca is poised to become an open pit mine without any control, Colomb. Support Network, Peace Justice 
Hydrol. Earth Syst. Sci. Discuss., doi:10.5194/hess-2016-219, 2016

Manuscript under review for journal Hydrol. Earth Syst. Sci.

Published: 6 June 2016

(c) Author(s) 2016. CC-BY 3.0 License.

[online] Available from: http://colombiasupport.net/2010/12/the-cauca-is-poised-to-become-an-open-pit-mine-without-anycontrol/ (Accessed 15 October 2014), 2010.

McBride, G. B.: A proposal for strength-of-agreement criteria for Lin's Concordance Correlation Coefficient, Ministry of Health. National Institute of Water \& Atmospheric Research Ltd., NIWA Project MOH05201., 2005.

5 Meybeck, M.: Carbon, nitrogen, and phosphorus transport by world rivers, Am. J. Sci., 282, 401-450, 1982.

Meybeck, M., Laroche, L., Dürr, H. H. and Syvitski, J. P. M.: Global variability of daily total suspended solids and their fluxes in rivers, Glob. Planet. Change, 39(1-2), 65-93, 2003.

Ministerio de Desarrollo de Colombia: Inventario nacional del sector agua potable y saneamiento básico. Tomo I Infraestructura física de los sistemas, Ministerio de Desarrollo Económico, Viceministerio de Desarrollo Urbano, Dirección 10 de Servicios Públicos Domiciliarios, Bogotá D.C., Colombia., 1998.

Mitchell, A., Reghenzani, J., Faithful, J., Furnas, M. and Brodie, J.: Relationships between land use and nutrient concentrations in streams draining a wet-tropicstropics catchment in northern Australia, Mar. Freshw. Res., 60(11), 1097$1108,2009$.

Mitchell, P. and Prepas, E. E.: Atlas of Alberta Lakes, edited by P. Mitchell and E. E. Prepas, University of Alberta Press., 151990.

Mora, J. J. and Durán, J.: Impacto de la Ley Paez sobre el medio ambiente, Centro de Investigación en Economía y Finanzas, Cienfi, Universidad Icesi, Cali, Colombia., 2006.

Mulliss, R. M., Revitt, D. M. and Shutes, R. B.: The impacts of urban discharges on the hydrology and water quality of an urban watercourse, Sci. Total Environ., 189-190, 385-390, 1996.

20 Nadon, M. J., Metcalfe, R. A., Williams, C. J., Somers, K. M. and Xenopoulos, M. A.: Assessing the effects of dams and waterpower facilities on riverine dissolved organic matter composition, Hydrobiologia, 744(1), 145-164, 2015.

Nordin Jr., C. F. and Dempster Jr., G. R.: Vertical distribution of velocity and suspended sediment, Middle Rio Grande, New Mexico: sediment transport in alluvial channels, United States Government Printing Office, Geological Survey Professional Paper 462-B, Washington D.C., USA., 1963.

25 Packman, J. J., Comings, K. J. and Booth, D. B.: Using turbidity to determine total suspended solids, in Confronting Uncertainty - Managing Change in Water Resources and the Environment, pp. 158-165, Canadian Water Resources Association Annual Meeting, Vancouver, Canada., 1999.

PDA: Diagnóstico técnico de acueducto y alcantarillado en el área urbana, Plan Departamental del Agua, PDA Valle del Cauca. Alcaldía de Santiago de Cali., 2008.

30 Pérez-Rincón, M. A.: Conflictos ambientales en Colombia: inventario, caracterización y análisis, in Minería en Colombia, edited by CGR, pp. 253-325, Contraloría General de la República, Bogotá D.C., Colombia., 2014.

Pérez-Vidal, A., Delgado-Cabrera, L. G. and Torres-Lozada, P.: Evolución y perspectivas del sistema de abastecimiento de la ciudad de Santiago de Cali frente al aseguramiento de la calidad del agua potable, Ing. y Compet., 14(2), 69-81, 2012. PGN: Mineria ilegal en Colombia. Informe Preventivo, Procuraduría General de la Nación, Bogotá D.C., Colombia., 2011. 
Hydrol. Earth Syst. Sci. Discuss., doi:10.5194/hess-2016-219, 2016

Manuscript under review for journal Hydrol. Earth Syst. Sci.

Published: 6 June 2016

(c) Author(s) 2016. CC-BY 3.0 License.

Pinzón, L. F. and Sotelo, H.: Efectos de los cultivos ilícitos sobre el medio natural en Colombia, Rev. Gestión Integr. en Ing. Neogranadina, 3(2), 123-133, 2011.

Quimbayo, G. A.: Cultivos de uso ilícito y ecocidio, Transnational Institute, Informe sobre políticas de drogas No. $28 ., 2008$.

Ramírez, C. A., Santacruz, S., Bocanegra, R. A. and Sandoval, M. C.: Incidencia del embalse de Salvajina sobre el régimen

5 de caudales del río Cauca en su Valle Alto, Ing. Recur. Nat. y del Ambient., 9(9), 89-99, 2010.

Reyes, R. A.: Definición de objetivos de calidad del agua en corrientes superficiales, en el área de jurisdicción de la CRC, Undergraduate Thesis, Universidad del Cauca, Colombia., 2009.

Riera, J. L. and Armengol, J.: Relationship between seston composition and water transparency in Spanish reservoirs, Int. Rev. der gesamten Hydrobiol. und Hydrogr., 80(1), 1-14, 1995.

10 Rodríguez, C.: Las lluvias, ¿responsables por deslizamientos e inundaciones?. Plan Nacional de Desarrollo, las propuestas del gremio, Infraestruct. y Desarro., 39, 2011.

Skidmore, R. E., Maberly, S. C. and Whitton, B. A.: Patterns of spatial and temporal variation in phytoplankton chlorophyll a in the River Trent and its tributaries, Sci. Total Environ., 210-211, 357-365, 1998.

Smayda, T. J.: Turbulence, watermass stratification and harmful algal blooms: an alternative view and frontal zones as

15 "pelagic seed banks," Harmful Algae, 1(1), 95-112, 2002.

Susfalk, R. B., Fitzgerald, B. and Knust, A. M.: Suspended solids in the Upper Carson River, Nevada., 2008.

Toy, T. J., Foster, G. R. and Renard, K. G.: Soil erosion: processes, prediction, measurement, and control, John Wiley \& Sons, Inc., New York, USA., 2002.

UNESCO: Water quality assessments - a guide to use of biota, sediments and water in environmental monitoring, 2nd ed.,

20 edited by D. Chapman, UNESCO/WHO/UNEP, London, U.K., 1996.

Universidad del Valle and UNESCO-IHE: Urban water management for the city of Cali, Diagnosis report: the sewerage system of the city of Cali, p. 34, Sustainable Water Management Improves Tomorrow's Cities' Health, SWITCH Project, Cali, Colombia., 2008.

UNODC: Colombia - monitoreo de cultivos de coca 2012, Bogotá D.C., Colombia., 2013.

25 UPME: Mining districts: exports \& transportation infraestructure, Unidad de Planeación Minero Energética - UPME, Bogotá D.C., Colombia., 2005.

Vélez, C. A., Galvis, A., Ramírez, C. A. and Baena, L. M.: Cauca River water quality model hydroinformatics application in a developing country, in 7th International Conference on Hydroinformatics - HIC, pp. 1-8, Nice, France., 2006.

Volk, C., Wood, L., Johnson, B., Robinson, J., Zhu, H. W. and Kaplan, L.: Monitoring dissolved organic carbon in surface 30 and drinking waters, J. Environ. Monit. - JEM, 4(1), 43-47, 2002.

Wu, J. L., Ho, C. R., Huang, C. C., Srivastav, A. L., Tzeng, J. H. and Lin, Y. T.: Hyperspectral sensing for turbid water quality monitoring in freshwater rivers: empirical relationship between reflectance and turbidity and total solids, Sensors, 14(12), 22670-22688, 2014.

Zibechi, R.: Mining and post-conflict in Colombia, Am. Program, a new world action Commun. Soc. Chang. [online] 
Hydrol. Earth Syst. Sci. Discuss., doi:10.5194/hess-2016-219, 2016

Manuscript under review for journal Hydrol. Earth Syst. Sci.

Published: 6 June 2016

(C) Author(s) 2016. CC-BY 3.0 License.
Hydrology and

Earth System

Sciences

Discussions

(c) (1)

Available from: http://www.cipamericas.org/archives/12465 (Accessed 30 September 2014), 2014.

Ziegler, A. D., Lu, X. X. and Tantasarin, C.: Sediment load monitoring in the Mae Sa catchment in northern Thailand, in Sediment Problems and Sediment Management in Asian River Basins, pp. 86-91, Hyderabad, India., 2011.

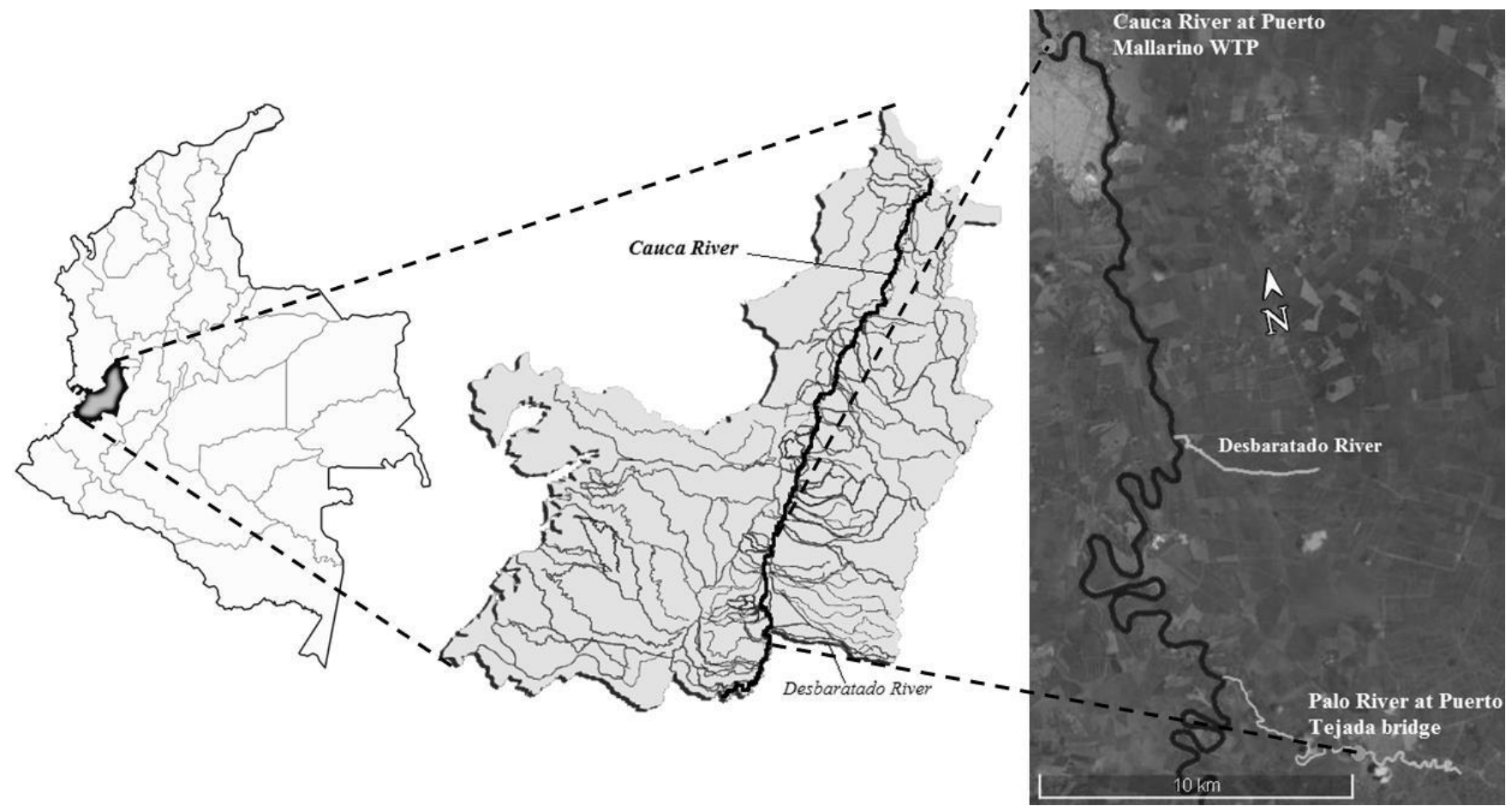

Figure 1: Cauca River at Puerto Mallarino water intake and its tributary Palo River
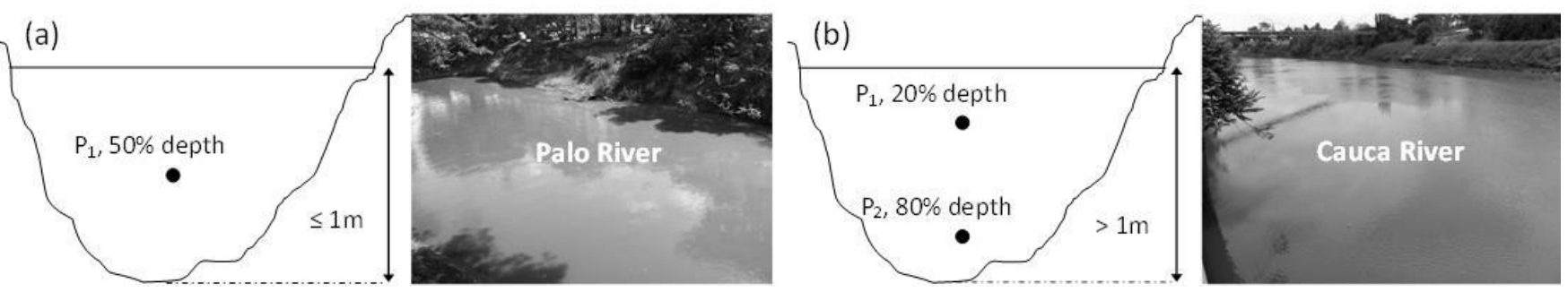

Figure 2: Sampling points for (a) Palo River and (b) Cauca River 
Hydrol. Earth Syst. Sci. Discuss., doi:10.5194/hess-2016-219, 2016

Manuscript under review for journal Hydrol. Earth Syst. Sci.

Published: 6 June 2016

(c) Author(s) 2016. CC-BY 3.0 License.

\section{(c) (i)}

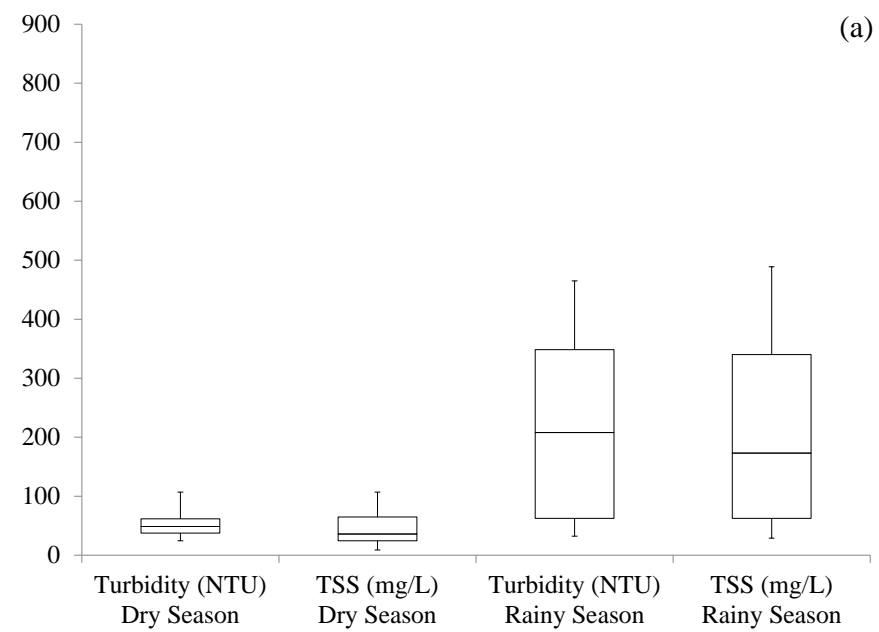

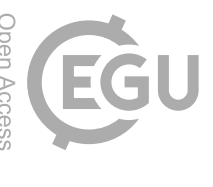

(a) 900

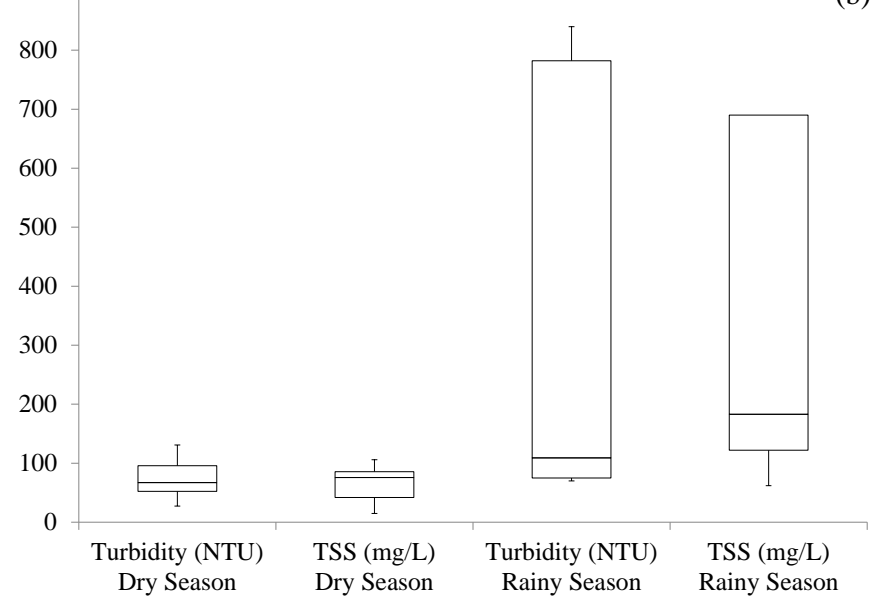

Figure 3: Boxplots of turbidity and TSS in Cauca River (a) and Palo River (b). The line through the middle is the median value. The top and bottom lines correspond to the $75^{\text {th }}$ and $25^{\text {th }}$ percentile, respectively. The whiskers extend to the minimum value at the bottom and the maximum value on top
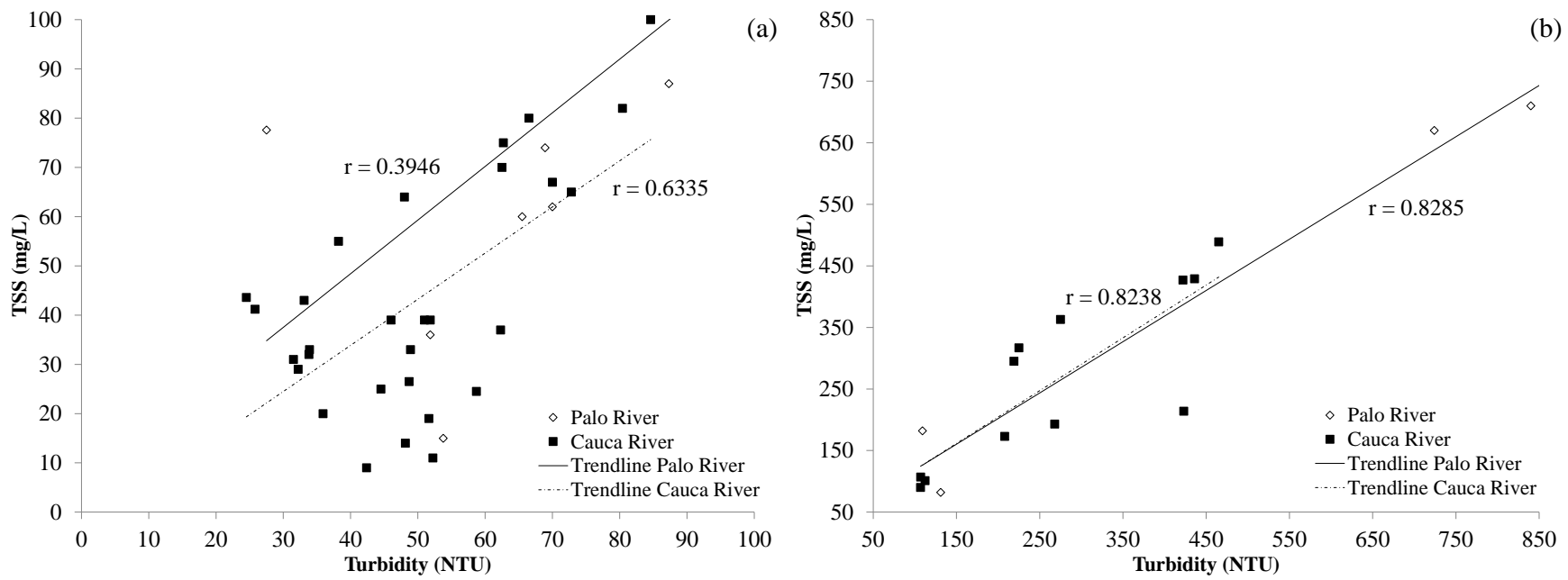

Figure 4: Relationship between turbidity and TSS for Cauca River and Palo River during dry (a) and rainy (b) season 
Hydrol. Earth Syst. Sci. Discuss., doi:10.5194/hess-2016-219, 2016

Manuscript under review for journal Hydrol. Earth Syst. Sci.

Published: 6 June 2016

(c) Author(s) 2016. CC-BY 3.0 License.
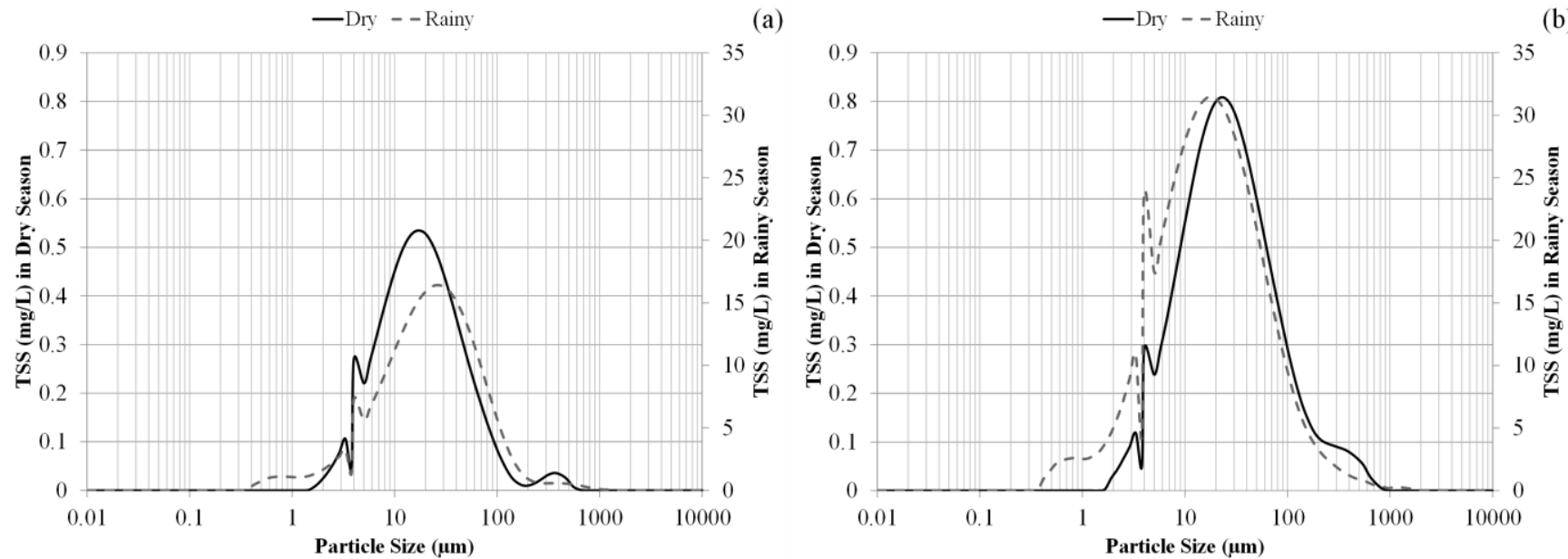

Figure 5: TSS distributed by particle size for: Cauca River during dry and rainy season (a) and Palo River during dry and rainy season $(b)$

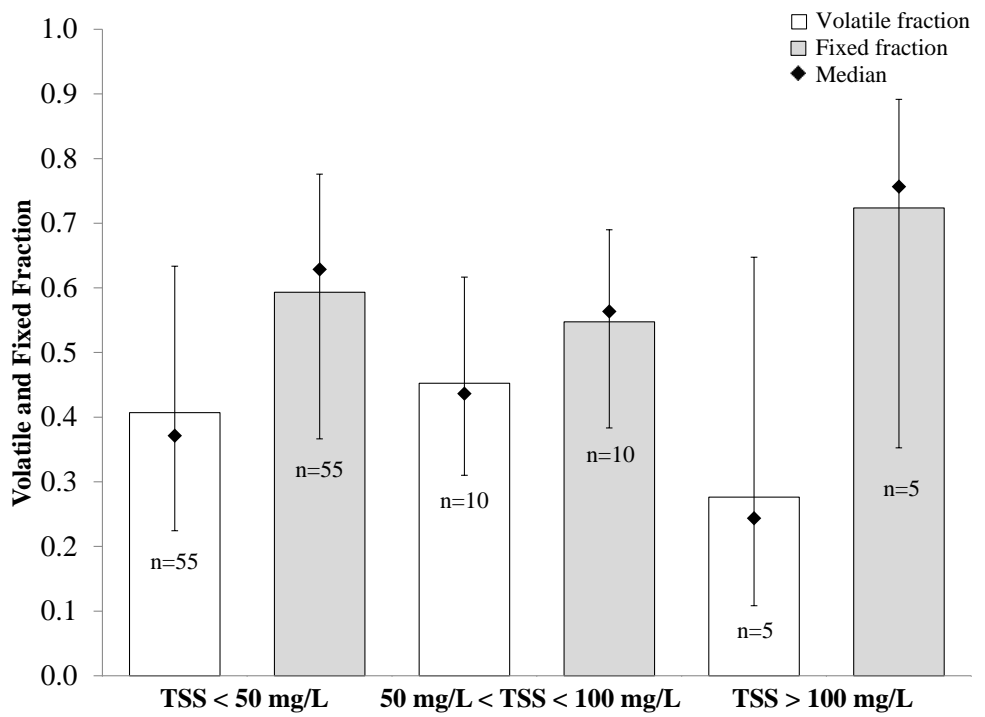

5 Figure 6: VSS fraction related to TSS. The top line of the bar is the arithmetic mean of the samples. The point represents the median value. The whiskers extend to the minimum value at the bottom and the maximum value at the top 
Hydrol. Earth Syst. Sci. Discuss., doi:10.5194/hess-2016-219, 2016

Manuscript under review for journal Hydrol. Earth Syst. Sci.

Published: 6 June 2016

(c) Author(s) 2016. CC-BY 3.0 License.

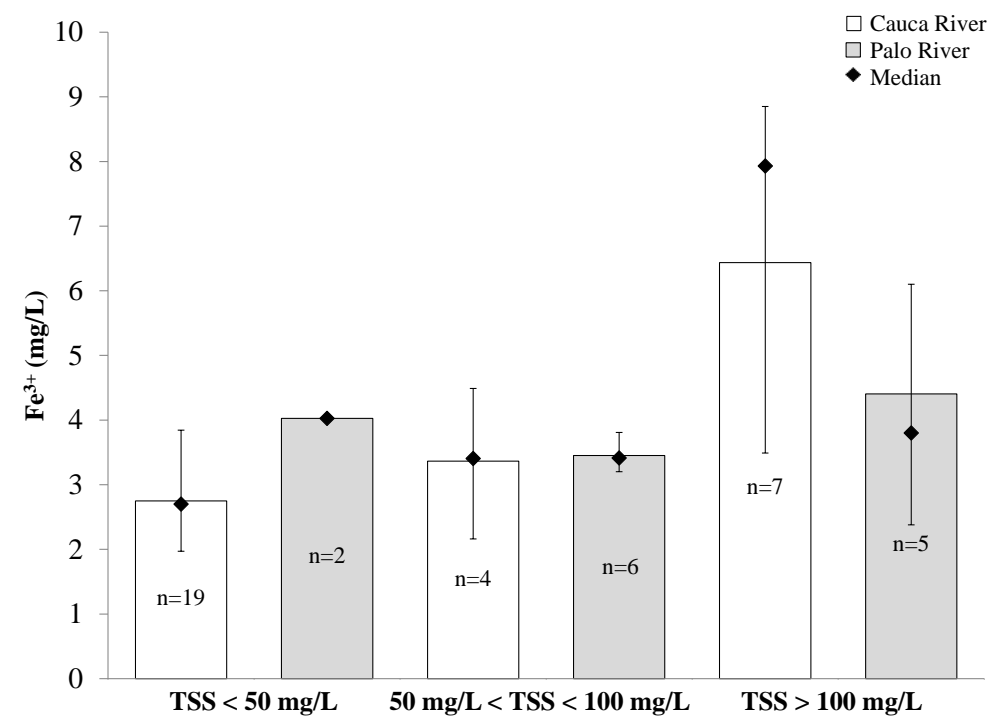

Figure 7: TSS and non-soluble iron. The top line of the bar is the arithmetic mean of the samples. The point represents the median value. The whiskers extend to the minimum value at the bottom and the maximum value at top

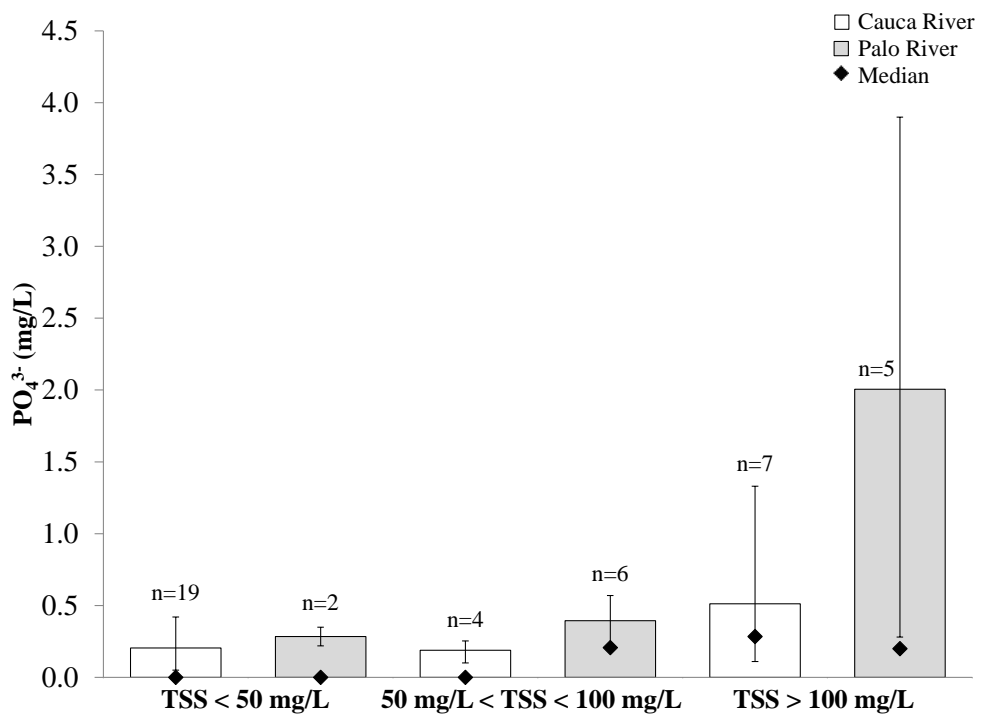

5 Figure 8: TSS and phosphate. The top line of the bar is the arithmetic mean of the samples. The point represents the median value. The whiskers extend to the minimum value at the bottom and the maximum value at top

Table 1: Systematic overview of potential sources of particulate matter

\begin{tabular}{|c|c|c|c|c|}
\hline Source & Compounds & Seasonal & Observations & Reference \\
\hline Agriculture & $\begin{array}{l}\text { Sand, clay, } \\
\text { phosphates, }\end{array}$ & $\begin{array}{l}\text { higher during / } \\
\text { after rain }\end{array}$ & $\begin{array}{lr}\text { Sugar cane } & \text { occupies } \\
\text { extensive } & \text { lands. }\end{array}$ & $\begin{array}{l}\text { Cifuentes } \\
\text { Conpes (2014; } \\
\text { (2009); CRC }\end{array}$ \\
\hline
\end{tabular}


Hydrol. Earth Syst. Sci. Discuss., doi:10.5194/hess-2016-219, 2016

Manuscript under review for journal Hydrol. Earth Syst. Sci.

\section{(c) (i)}

\begin{tabular}{|c|c|c|c|c|}
\hline Source & Compounds & Seasonal & Observations & Reference \\
\hline & $\begin{array}{l}\text { nitrates, } \\
\text { organics, sand, } \\
\text { microorganisms }\end{array}$ & $\begin{array}{l}\text { higher during } \\
\text { harvest }\end{array}$ & $\begin{array}{l}\text { Extensive and intensive } \\
\text { cattle breeding near } \\
\text { from the riverbanks. } \\
\text { Illicit crops in steep } \\
\text { areas beside water } \\
\text { sources }\end{array}$ & 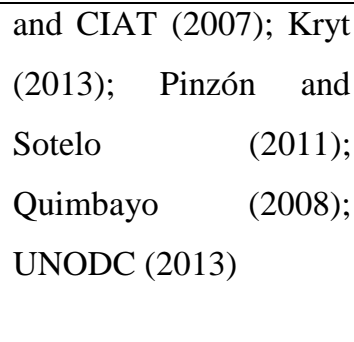 \\
\hline Deforestation & Sand, clay & $\begin{array}{l}\text { higher during / } \\
\text { after rain }\end{array}$ & & $\begin{array}{l}\text { Conpes (2009); CVC } \\
\text { and Universidad del } \\
\text { Valle (2004) }\end{array}$ \\
\hline $\begin{array}{l}\text { Industrial and } \\
\text { domestic } \\
\text { waste water }\end{array}$ & $\begin{array}{l}\text { Sand, organics, } \\
\text { clay, inorganic } \\
\text { chemicals; } \\
\text { heavy metals }\end{array}$ & $\begin{array}{l}\text { lower during / } \\
\text { after rain for } \\
\text { industries } \\
\text { discharging } \\
\text { directly into } \\
\text { Cauca River; } \\
\text { higher during / } \\
\text { after rain for } \\
\text { industries } \\
\text { discharging } \\
\text { into South } \\
\text { Canal }\end{array}$ & $\begin{array}{l}\text { Factories from the } \\
\text { Industrial and } \\
\text { Commercial Parks of } \\
\text { the Cauca department. } \\
\text { A storm water canal } \\
\text { (South Canal), located } \\
11 \text { km upstream of the } \\
\text { Puerto Mallarino WTP, } \\
\text { discharges into Cauca } \\
\text { River. This canal } \\
\text { collects industrial and } \\
\text { domestic wastewater, } \\
\text { and leachate from a } \\
\text { closed landfill }\end{array}$ & $\begin{array}{l}\text { Conpes (2009); Hurtado } \\
\text { (2014); Mora and } \\
\text { Durán (2006); } \\
\text { Universidad del Valle } \\
\text { and UNESCO-IHE } \\
(2008) \text {; Vélez et al. } \\
(2006)\end{array}$ \\
\hline Mining & $\begin{array}{l}\text { Sand, clay, } \\
\text { ferric oxides, } \\
\text { mercury, } \\
\text { cyanide }\end{array}$ & $\begin{array}{l}\text { higher during / } \\
\text { after rain }\end{array}$ & $\begin{array}{l}\text { Coal, magnesite, } \\
\text { bentonite, feldspar, } \\
\text { bauxite and gold } \\
\text { mining (open-pit and } \\
\text { underground). Artisanal } \\
\text { and high scale miners } \\
\text { extracting gold in } \\
\text { tributary rivers }\end{array}$ & $\begin{array}{l}\text { Kryt (2013); López } \\
(2010) ; \quad \text { Pérez-Rincón } \\
\text { (2014); PGN (2011); } \\
\text { UPME (2005) }\end{array}$ \\
\hline Construction & Sand, clay & higher during / & & Conpes (2009) \\
\hline
\end{tabular}


Hydrol. Earth Syst. Sci. Discuss., doi:10.5194/hess-2016-219, 2016

Manuscript under review for journal Hydrol. Earth Syst. Sci.

Published: 6 June 2016

(c) Author(s) 2016. CC-BY 3.0 License.

\section{(c) (1)}

\begin{tabular}{|c|c|c|c|c|}
\hline Source & Compounds & Seasonal & Observations & Reference \\
\hline / urbanization & & after rain & & \\
\hline $\begin{array}{l}\text { Illegal slums } \\
\text { on riverbanks }\end{array}$ & $\begin{array}{l}\text { Sand, organics, } \\
\text { phosphates, } \\
\text { nitrates, clay }\end{array}$ & $\begin{array}{l}\text { lower during / } \\
\text { after rain }\end{array}$ & $\begin{array}{l}\text { Slums along the Cauca } \\
\text { riverbed: solid waste } \\
\text { and wastewater }\end{array}$ & $\begin{array}{l}\text { Universidad del Valle } \\
\text { and UNESCO-IHE } \\
\text { (2008) }\end{array}$ \\
\hline $\begin{array}{l}\text { River sand } \\
\text { exploitation }\end{array}$ & Sand, clay & $\begin{array}{l}\text { lower during / } \\
\text { after rain }\end{array}$ & $\begin{array}{l}\text { Sand and stone } \\
\text { aggregates extracted } \\
\text { from riverbed }\end{array}$ & $\begin{array}{l}\text { CVC and Universidad } \\
\text { del Valle (2004); } \\
\text { UPME (2005) }\end{array}$ \\
\hline $\begin{array}{l}\text { Forest fires } \\
\text { and/or } \\
\text { burning }\end{array}$ & $\begin{array}{l}\text { Organics, sand, } \\
\text { clay }\end{array}$ & & $\begin{array}{l}\text { Sugar cane burning } \\
\text { causing vegetation loss }\end{array}$ & Pérez-Rincón (2014) \\
\hline $\begin{array}{l}\text { Natural } \\
\text { disasters }\end{array}$ & $\begin{array}{l}\text { Ferric oxides, } \\
\text { sand, clay }\end{array}$ & $\begin{array}{l}\text { higher during / } \\
\text { after rain }\end{array}$ & $\begin{array}{l}\text { ENSO and La Niña } \\
\text { causing flooding and } \\
\text { droughts }\end{array}$ & (Rodríguez, 2011) \\
\hline
\end{tabular}

Table 2: Identified particulate matter sources

\begin{tabular}{|c|c|c|c|c|c|c|c|c|c|c|c|c|c|c|c|c|}
\hline \multirow{2}{*}{$\begin{array}{ll} & \text { Parameter } \\
& \\
\text { Source } & \end{array}$} & \multicolumn{8}{|c|}{ Expected results } & \multicolumn{8}{|c|}{ Findings from this survey } \\
\hline & 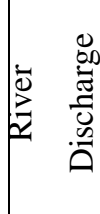 & 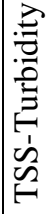 & 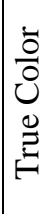 & $\overbrace{}^{+}$ & $\oint_{z}^{m}$ & $\stackrel{0}{0}$ & $\begin{array}{l}+ \\
+ \\
\text { w } \\
\text { II }\end{array}$ & $\hat{\tilde{2}}$ & 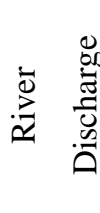 & 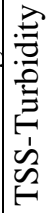 & 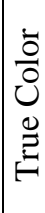 & $\overbrace{}^{+}$ & $\oint_{z}^{m}$ & Oి & $\begin{array}{l}+ \\
m_{0} \\
\text { II }\end{array}$ & $\hat{\curvearrowleft}$ \\
\hline \multirow{2}{*}{$\begin{array}{l}\text { Natural erosion } \\
\text { - Riverbank erosion } \\
\text { (shear stress forces) }\end{array}$} & High & + & + & - & - & - & - & + & \multirow{4}{*}{ High } & \multirow{4}{*}{+} & \multirow{4}{*}{+} & \multirow{4}{*}{+} & \multirow{4}{*}{+} & \multirow{4}{*}{+} & \multirow{4}{*}{+} & \multirow{4}{*}{-} \\
\hline & Low & - & - & - & - & - & - & - & & & & & & & & \\
\hline \multirow{2}{*}{$\begin{array}{l}\text { Human erosion } \\
\text { - Deforestation } \\
\text { - Agriculture }\end{array}$} & High & - & - & - & - & - & - & - & & & & & & & & \\
\hline & Low & + & + & + & + & + & + & - & & & & & & & & \\
\hline \multirow{2}{*}{ Mining } & High & + & + & - & - & - & - & + & \multirow{4}{*}{ Low } & \multirow{4}{*}{+} & & \multirow{4}{*}{+} & \multirow{4}{*}{+} & \multirow{4}{*}{+} & \multirow{4}{*}{+} & \multirow{4}{*}{+} \\
\hline & Low & + & + & + & + & + & + & + & & & & & & & & \\
\hline \multirow{2}{*}{$\begin{array}{l}\text { Point discharges } \\
\text { - Industry } \\
\text { - Domestic waste water }\end{array}$} & High & - & - & - & - & - & - & - & & & & & & & & \\
\hline & Low & + & + & + & + & + & + & - & & & & & & & & \\
\hline
\end{tabular}

+ : increase -: decrease 